Керамова С.Н., Раджабова М.М. Понятие и основные черты административного правонарушения как основания административной ответственности

УДК 342

DOI: $10.21779 / 2500-1930-2016-31-4-78-84$

\title{
С.Н. Керамова, М.М.Раджабова
}

\section{Понятие и основные черты административного правонарушения как основания административной ответственности}

Дагестанский государственный университет; Россия, 367001, г. Махачкала, ул. М. Гаджиева, 43a; saida14@yandex.ru

В статье рассматриваются актуальные вопросы административного правонарушения как основания административной ответственности. Актуальность темы статьи обуславливается тем, что комплексное изучение административного правонарушения имеет большое значение в условиях современной России, когда неуклонно растет число правонарушений, в том числе административных, тогда как в стране поставлена задача построения правового государства и гражданского общества.

Целью статьи является определение понятия и основных признаков административного правонарушения как основания административной ответственности. Дана общая характеристика административного правонарушения на основе действующего законодательства. Приводятся позиции ученых относительно определения понятия административного правонарушения как основания административной ответственности. Характеризуются признаки административного правонарушения. Рассматривается содержание административной ответственности, условия ее применения.

Акцентируется внимание на проблеме общественной вредности или общественной опасности административного правонарушения. Проводится сопоставление категорий «административное правонарушение» и «административная ответственность». Результатом исследования является формулирование выводов и предложений по совершенствованию административного законодательства и исследованию сущности административного правонарушения.

Ключевые слова: административное правонарушение, административная ответственность, признаки, основание административной ответственности.

Исследование сущности административного правонарушения очень важно для юридической науки, особенно в современных условиях Российской Федерации, когда, во-первых, растет количество правонарушений, в том числе административных, и, вовторых, стоит задача построения правового государства и гражданского общества [1, с. 113].

В первую очередь определим, что же такое административное правонарушение. Согласно части 1 статьи 2.1 КоАП РФ, административное правонарушение - это «противоправное, виновное действие (бездействие) физического или юридического лица, за которое настоящим Кодексом или законами субъектов Российской Федерации об административных правонарушениях установлена административная ответственность» [2]. Как видим, административное правонарушение представляет собой деяние, которое может проявляться в двух формах: действии и бездействии. Из определения, данного в КоАП, напрямую вытекают такие признаки административного правонарушения, как противоправность, виновность и наказуемость.

Многие ученые-административисты придерживаются позиции, согласно которой административная ответственность наступает в том случае, если совершено административное правонарушение, их общее мнение сводится к тому, что «административное 
Керамова С.Н., Раджабова М.М. Понятие и основные черты административного правонарушения как основания административной ответственности

правонарушение является основанием для привлечения к административной ответственности» [3, с. 86].

Для раскрытия вопроса об административном правонарушении как основании административной ответственности в первую очередь представляется правильным дать определение понятия административного правонарушения, его характерных признаков и отличий от других правонарушений. В юридической литературе разработано большое количество различных определений административного правонарушения. К примеру, по мнению С.С. Студеникина, административное правонарушение - это «нарушение административно-правовой нормы, наказание за которое налагается властью органа государственного управления, а не в судебном порядке» [4, с. 133]. О.М. Якуба считает, что административное правонарушение - это «нарушение или неисполнение административно-правовых норм, устанавливающих определенные правила в различных отраслях управления и снабженных административной санкцией» [5, с. 34]. А.В. Серегин говорит об административном правонарушении, как «о виновном антиобщественном деянии (действии или бездействии), нарушающем общественные правила поведения, охраняемые мерами административного воздействия» [6, с. 19]. Как представляется, для этих определений характерны смысловая незавершенность, недостаточная развитость самой административно-правовой теории о правонарушениях, в них отсутствует ряд важных правовых компонентов.

Интересным представляется определение И.А. Галагана - «общественно вредные действия или бездействия, нарушающие предписания административно-правовых норм, обеспеченных санкциями в виде конкретных наказаний, и регулируемые ими общественные отношения в сфере государственного управления, которые отличаются от преступлений меньшей степенью общественной опасности, а потому и влекут за собой административную ответственность» [7, с. 232], который предусмотрел почти все важнейшие правовые особенности данного правового явления. Схожего мнения придерживаются профессор В.В. Головко и профессор В.И. Майоров, которые дают свое определение: «административным правонарушением признается посягающее на права, свободы и безопасность граждан, собственность, установленный порядок управления, общественно вредное, противоправное, виновное (умышленное или неосторожное) действие или бездействие, за которое федеральным законодательством и законами субъектов Российской Федерации предусмотрена административная ответственность» $[8$, c. 63].

Рассматривая административное правонарушение как основание наступления юридической ответственности, предпочтительным представляется определение, данное В.В. Головко и В.И. Майоровым.

На основе юридического анализа определений, данных учеными-юристами, можно выделить следующие характерные признаки административного правонарушения:

1) общественная вредность. Напрямую данный признак в легальном определении не закреплен, соответственно не является материальным признаком административного правонарушения, но о наличии его косвенно свидетельствует ст. 2.2 КоАП РФ, где говорится о «вредных последствиях» этого деяния;

2) противоправность деяния означает, что данное деяние закреплено в нормативном правовом акте как правонарушение, т. е. такое действие (бездействие) прямо предусмотрено в качестве административного правонарушения в КоАП РФ и законах субъектов Российской Федерации об административных правонарушениях; 
Керамова С.Н., Раджабова М.М. Понятие и основные черты административного правонарушения как основания административной ответственности

3) виновность деяния подразумевает, что оно совершено при наличии вины в форме умысла или неосторожности, т. е. совершено умышленно либо неосторожно;

4) субъектный состав. Субъектами правонарушения могут быть как физические, так и юридические лица;

5) наказуемость как признак административного правонарушения означает возможность применения административного наказания за совершение данного правонарушения. Административные наказани, в свою очередь, как «мера административной ответственности подразумевают применение различных средств принудительного воздействия на поведение людей» [9, с. 15].

Наиболее дискуссионным среди ученых-административистов является вопрос об общественной вредности или общественной опасности административного правонарушения. Согласно Кодексу об административных правонарушениях (в ред. 2016 г.) «общественная опасность административного правонарушения состоит в том, что оно реально причиняет или может причинить вред общественным отношениям, охраняемым законом». Суть дискуссии состоит в том, что учеными предлагается различное толкование данного признака - или как общественно опасного, или как общественно вредного. К примеру, профессор В.В. Головко и профессор В.И. Майоров считают, что «они не обладают общественной опасностью - это общественно вредные, антиобщественные деяния» [8, с. 63]. Однако мы не согласны с таким высказыванием. Думается, говорить о том, что административные правонарушения посягают на охраняемые государством общественные отношения всё же стоит. По мнению ряда ученых, с которыми мы солидарны, «общественная опасность административного правонарушения состоит в том, что они реально причиняют или могут причинить вред общественным отношениям, охраняемым законом. Вред может выражаться как в причинении материального ущерба, так и в иной форме» [7, с. 232]. Также считает В.А. Ковалев, отмечая, что правонарушение как противоправное виновное деяние (действие или бездействие) причиняет или способно причинить вред обществу, государству, отдельным лицам.

Как основание административной ответственности административное правонарушение содержит юридический состав - определенные элементы, только при наличии которых может наступить административная ответственность. Предусматривается четыре элемента состава правонарушения: объект, объективная сторона, субъект и субъективная сторона. Объект административного правонарушения - это общественные отношения, за посягательство на которые установлена административная ответственность. Другими словами, то, на что посягает противоправное деяние: государственный или общественный порядок, права и свободы граждан, все формы собственности, установленный порядок управления [10, с. 128]. Объективная сторона - это внешняя характеристика, внешнее проявление совершенного противоправного деяния. Она характеризует административное правонарушение как противоправный акт поведения правонарушителя. Из анализа действующего административного законодательства следует, что в объективной стороне административного правонарушения можно выделить такие основные признаки, как «противоправность деяния (действия или бездействия), противоправный результат (вред, ущерб материального или нематериального характера), прямую причинную связь между деянием и результатом» [1, с. 114]. Как представляется, для материальных составов наличие причинной связи между деянием и вредными последствиями является непременной характеристикой.

Субъектом административного правонарушения согласно КоАП РФ (ст. 2.1) могут быть как физические, так и юридические лица. Для физических лиц минимальный возраст привлечения к административной ответственности составляет 16 лет. Субъек- 
Керамова С.Н., Раджабова М.М. Понятие и основные черты административного правонарушения как основания административной ответственности

тивная сторона административного правонарушения включает вину, мотивы правонарушения и его цель. Вина является основным элементом субъективной стороны.

Следует подчеркнуть, что в Особенной части КоАП РФ все виды правонарушений объединены в классификационные группы. Для выявления состава административного правонарушения необходимо прежде всего комплексно исследовать все элементы правонарушения.

Таким образом, при наличии юридического состава административного правонарушения наступает административная ответственность, то есть основание административной ответственности составляет административное правонарушение. В этом можно увидеть тесную взаимосвязь и взаимообусловленность между административным правонарушением и административной ответственностью: «с одной стороны, без правонарушения нет административной ответственности, а с другой - основанием административной ответственности выступает правонарушение» [8, с. 62].

Содержание института административной ответственности составляют нормы Общей части КоАП РФ, провозглашающие принципы равенства перед законом лиц, совершивших административные правонарушения (ст. 1.4), а также некоторые нормы Особенной части КоАП РФ.

В юридической литературе существуют различные суждения о содержании административной ответственности. Например, О.М. Якуба и Д.Н. Бахрах полагают, что «под административной ответственностью следует понимать применение государственными органами и должностными лицами в условиях внеслужебного подчинения административных санкций за правонарушение» [11, с. 41]. В.Р. Кисин и Ю.И. Попугаев представляют административную ответственность «как установленное законом правовое последствие совершения административного правонарушения, состоящее в возложении на правонарушителя обязанности претерпеть лишения и правоограничения, которые закон связывает с совершением административного правонарушения, и реализация этой обязанности посредством правоприменительной деятельности уполномоченных органов и должностных лиц, осуществляемой в установленном законом порядке» [12, с. 95].

Существует и множество других определений. Однако ни одно из них не противоречит признанию административной ответственности правовым последствием совершения административного правонарушения.

Анализируя понятие административного правонарушения как основание административной ответственности, представляется необходимым в первую очередь выяснить, на чем основана административная ответственность. Если рассматривать ее как правоотношение, то можно сказать, что субъектами этих правоотношений являются две стороны: первой стороной - государство, его компетентные органы и должностные лица, второй - лицо, совершившее противоправное деяние, т. е. правонарушитель. Для указанных сторон в данных правоотношениях характерно наличие административноправового статуса - комплекс прав и обязанностей. Совокупность прав и обязанностей, возникающих и реализуемых в административно-деликтных отношениях, устанавливается в действующем законодательстве, т. е. имеет нормативную правовую основу.

Значит, можно сказать, что существование административной ответственности как правоотношения и как явления возможно только при условии ее нормативного правового обоснования. Согласно действующему российскому законодательству административную ответственность применяют к правонарушителю за совершение им административного правонарушения. Особенность административных правонарушений состоит в том, что они обычно не влекут серьезных вредных последствий. Большая часть 
Керамова С.Н., Раджабова М.М. Понятие и основные черты административного правонарушения как основания административной ответственности

административных правонарушений являются нарушениями установленных государством правил должного или возможного поведения в целях недопущения вредных последствий. По общему правилу основанием применения административной ответственности выступают действия (бездействия), совершение которых не повлекло наступления вредных последствий. К примеру, управление транспортными средствами водителями или иными лицами в состоянии опьянения, а также передача и допуск к управлению транспортным средством лица, которое находится в состоянии опьянения. Объектом этого административного правонарушения являются общественные отношения в сфере безопасности дорожного движения [7, с. 223].

Таким образом, в случае если отсутствуют обстоятельства, исключающие административную ответственность, предусмотренные ст. 24.5 КоАП РФ, то к лицу, совершившему административное правонарушение, могут применяться следующие виды административного наказания, предусмотренные ст. 3.2КоАП РФ: «предупреждение; административный штраф; конфискация орудия совершения или предмета правонарушения; лишение специального права, предоставленного физическому лицу; административный арест; административное выдворение за пределы Российской Федерации иностранного гражданина или лица без гражданства; дисквалификация; административное приостановление деятельности; обязательные работы; административный запрет на посещение мест проведения официальных спортивных соревнований в дни их проведения». Этот перечень является исчерпывающим, устанавливается исключительно Кодексом об административных правонарушениях Российской Федерации согласно части 1 статьи 1.3 КоАП РФ.

В заключение можно сделать следующие выводы.

Юридический анализ понятия административного правонарушения позволяет выявить наиболее специфические особенности, свойственные этому правонарушению: общественную опасность, противоправность, виновность, наказуемость. Все эти признаки только в совокупности влекут административную ответственность. Отсутствие хотя бы одного из указанных признаков означает, что данное деяние не является административным правонарушением. Применение административной ответственности должно четко регламентироваться законом. Меры административной ответственности надо применять только в случае выявления и оформления фактически совершенного противоправного деяния, запрещенного законодателем, за которое следует наказание.

Определение административного правонарушения, имеющегося в административном законодательстве, нуждается в дальнейшем совершенствовании в связи с тем, что в первую очередь в научной литературе по-прежнему остается спорным вопрос об общественной опасности административного правонарушения. Только комплексное исследование сущности административного правонарушения позволит должным образом характеризовать административное правонарушение (его признаки и состав) как основание административной ответственности.

\section{Литература}

1. Нактанов К.К., Мукабенов М.В., Ангрыкова Г.М. Административное правонарушение как основание административной ответственности: теоретические основы и их воплощение на практике // Вестник Калмыцкого университета. - 2013. - № 1 (17).

2. Кодекс Российской Федерации об административных правонарушениях от 30 декабря 2001 г. № 195-Ф3: в ред. 3 окт. 2016 г. Доступ из справ.-правовой системы «КонсультантПлюс». 
Керамова С.Н., Раджабова М.М. Понятие и основные черты административного правонарушения как основания административной ответственности

3. Камасова А.Г. Административное правонарушение как основание административной ответственности сотрудников органов внутренних дел // Вестник Московского университета МВД России. - 2015. - № 6.

4. Студеникин С.С. Советское административное право. М.: Юрид. изд-во НКЮ СССР, 1945.

5. Якуба О.М. Административная ответственность. - М.: Юрид. лит., 1972.

6. Серегин A.B. Советский общественный порядок и административноправовые средства его укрепления. - М., 1975.

7. Бакиров У., Ормонов Э.А.Административное правонарушение как основание административной ответственности // Известия вузов Кыргызстана. - 2015. - № 5.

8. Головко В.В., Майоров В.И.Правонарушение как фактическое основание административной ответственности // Алтайский юридический вестник. - 2016. - № 2 (14).

9. Зырянов С.M. Административная ответственность в системе публичноправовой ответственности // Журнал российского права. - 2014. - № 1(205).

10. Мурзаибраимов Н.Б. Юридический состав административного правонарушения // Наука и новые технологии. - 2011. -№ 9.

11. Бахрах Д.Н. Система субъектов советского административного права // Советское государство и право. - 1986. - № 2.

12. Кисин В.Р., Попугаев Ю.И.Содержание административной ответственности, состояние и проблемы ее правового регулирования// Вестник Московского университета МВД России. - 2015. - № 6.

\section{References}

1. Naktanov K.K., Mukabenov M.V., Angrykova G.M. Administrativnoe pravonarushenie kak osnovanie administrativnoi otvetstvennosti: teoreticheskie osnovy i ikh voploshchenie na praktike // Vestnik Kalmytskogo universiteta. - 2013. - № 1 (17).

2. KodeksRossiiskoiFederatsiiobadministrativnykhpravonarusheniyakhot 30 dek. 2001 g. № 195-FZ: vred. ot 3 okt. 2016 g. Dostupizsprav.pravovoisistemy«Konsul'tantPlyus».

3. Kamasova A.G. Administrativnoe pravonarushenie kak osnovanie administrativnoi otvetstvennosti sotrudnikov organov vnutrennikh del // Vestnik Moskovskogo universiteta MVD Rossii. - 2015. - № 6.

4. Studenikin S.S. Sovetskoe administrativnoe pravo. - M.: Yurid. izd-vo NKYu SSSR, 1945.

5. Yakuba O.M. Administrativnaya otvetstvennost'. - M.: Yurid. lit., 1972.

6. Seregin A.V. Sovetskii obshchestvennyi poryadok i administrativno-pravovye sredstva ego ukrepleniya. M., 1975.

7. Bakirov U., Ormonov E.A.Administrativnoe pravonarushenie kak osnovanie administrativnoi otvetstvennosti // Izvestiya vuzov Kyrgyzstana. - 2015. - № 5.

8. Golovko V.V., Maiorov V.I. Pravonarushenie kak fakticheskoe osnovanie administrativnoi otvetstvennosti // Altaiskii yuridicheskii vestnik. - 2016. -№ 2 (14).

9. Zyryanov S.M. Administrativnaya otvetstvennost' v sisteme publichno-pravovoi otvetstvennosti // Zhurnal rossiiskogo prava. - 2014. -№ 1(205).

10. Murzaibraimov N.B. Yuridicheskii sostav administrativnogo pravonarusheniya // Nauka i novye tekhnologii. - 2011. -№ 9.

11. Bakhrakh D.N. Sistema sub»ektov sovetskogo administrativnogo prava // Sovetskoe gosudarstvo i pravo. - 1986. -№ 2. 
Керамова С.Н., Раджабова М.М. Понятие и основные черты административного правонарушения как основания административной ответственности

12. Kisin V.R., Popugaev Yu.I.Soderzhanie administrativnoi otvetstvennosti, sostoyanie i problemy ee pravovogo regulirovaniya // Vestnik Moskovskogo universiteta MVD Rossii. - 2015. - № 6 .

Поступила в редакичю 5 октября 2016 г.

UDC 342

DOI: $10.21779 / 2500-1930-2016-31-4-78-84$

\section{The concept and characteristics of administrative offence as the administrative responsibility base}

\section{S.N. Keramova, M.M. Radzhabova}

Dagestan State University; Russia, 367001, Makhachkala, M. Gadzhiyev st., 43a; saida14@yandex.ru

The article deals with current issues of administrative responsibility base. The relevance of the article is caused by the fact that a comprehensive study of the administrative offence is of great importance in today's Russia. The number of offences including administrative is steadily increasing whereas in the country the task of building the rule of law and civil society is set.

The aim of the article is to define the basic concepts and characteristics of administrative offences as administrative responsibility base. The general characteristic of administrative offense on the basis of existing legislation is given. Different scientists' approaches to the definition of administrative offenses as administrative responsibility base are given in the article. Characteristics of administrative offense, administrative responsibility content and the conditions of its application are also given.

The attention is focused on the problem of public harm or public danger of administrative offense. The categories "administrative offense" and "administrative responsibility" are compared. The result of the study is formulation of conclusions and proposals for the improvement of administrative law and the study of the nature of the administrative offense.

Keywords: administrative offense, administrative responsibility, the signs, the base of administrative responsibility.

Received5October, 2016 